\title{
The effects of Pongamia pinnata on osteogenic differentiation and mineralization of human stem cells derived from the gingiva
}

\author{
Hyunjin Lee ${ }^{1}$, Md. Salah Uddin², Yong-In Kim³ , Sangho Choi ${ }^{3}$, Jun-Beom Park ${ }^{1}$ \\ ${ }^{1}$ Department of Periodontics, College of Medicine, The Catholic University of Korea, Seoul, Republic of Korea \\ ${ }^{2}$ Ethnobotanical Database of Bangladesh, People's Republic of Bangladesh \\ ${ }^{3}$ International Biological Material Research Center, Korea Research Institute of Bioscience and Biotechnology, \\ Daejeon, Republic of Korea
}

\begin{abstract}
Objectives: The aim of the present study is to evaluate the effects of the extract of Pongamia pinnata on the morphology, viability, and differentiation potential of human stem cells derived from the gingiva.

Methods: Stem cells obtained from gingivae were cultured in an osteogenic medium in the presence of methanol extract of Pongamia pinnata (PPT) at concentrations ranging from 0.001 to $1 \%$. Evaluations of cell morphology and cellular viability were done at Day 1 . Alkaline phosphatase activity assays and Alizarin red S staining were performed to evaluate the osteogenic differentiation of stem cells.

Results: The morphology of stem cells in the presence of PPT at final concentrations of $0 \%, 0.001 \%, 0.01 \%, 0.1 \%$, and $1 \%$ did not produce any noticeable changes when compared with the untreated control group. Application of PPT produced a significant increase in alkaline phosphatase activity when compared to the control group. The results of the Alizarin Red S staining showed a significant increase of absorbance with the $0.001 \%$ group.

Conclusions: Based on these findings, it was concluded that PPT could produce beneficial effects on mesenchymal stem cells with enhanced osteogenic differentiation.
\end{abstract}

$\overline{\text { Key Words }}$ : cell differentiation, herbal medicine, Pongamia, stem cells

\section{Introduction}

Stem cells have unique properties, including the capability of dividing and renewing themselves and the ability to give rise to specialized cell types. ${ }^{1)}$ Stem cells have been applied in regenerative medicine. ${ }^{2)}$ Herbs have been used clinically for thousands of years, and these were suggested to be an effective source of therapeutics. ${ }^{3)}$ Moreover, in recent years, the effects of medicinal herbs on stem cells have been tested. ${ }^{3-5)}$ The application of Cimicifugae rhizoma increased cell proliferation without morphologic changes. ${ }^{5)}$ Similarly, Angelicae dahuricae radix produced a marginal increase in stem cell proliferation. ${ }^{4)}$

The effect of differentiation of stem cells has been of interest. A previous report suggested that the therapeutic potential of stem cells has limitations due to cell survival and differentiation capabilities.) Thus, the effects of herbal extracts on differentiation

\footnotetext{
- Received : 22 July 2017 •Revised : 25 November 2017 - Accepted : 1 December 2017

- Correspondence to : Jun-Beom Park

Department of Periodontics, Seoul St Mary's Hospital, College of Medicine, The Catholic University of Korea 222 Banpo-daero, Seocho-gu, Seoul, 06591, Republic of Korea

Tel : +82-10-4325-2651, Fax : +82-2-537-2374, E-mail : jbassoonis@yahoo.co.kr
} 
of stem cells have been studied. ${ }^{7,8)}$ Tanshinone from the Danshen herb is shown to enhance osteogenic differentiation of bone marrow mesenchymal stem cells. ${ }^{8)}$ Maohuoside A from Epimedium koreanum Nakai, one of the most used herbs in East Asia for curing osteoporosis, ${ }^{9,10)}$ is shown to promote osteogenesis of mesenchymal stem cells via BMP and MAPK signaling pathways. ${ }^{7)}$ Moreover, the effects of herbal extracts have been tested on stem cells derived from the intraoral area. Zanthoxylum schinifolium herbal extract is reported to enhance the osteogenic potential of periodontal ligament stem cells. ${ }^{11)}$ Pongamia pinnata (L.) Pierre has long been used in Oriental medicine to cure various diseases, including skin diseases and infectious diseases. ${ }^{12-15)}$ However, the effects of Pongamia pinnata on stem cells have rarely been tested. The aim of the present study is to evaluate the effects of the extract of Pongamia pinnata on the morphology, viability, and differentiation potential of human stem cells derived from the gingiva. Within the authors' knowledge, this investigation is the first to elucidate the effects of Pongamia pinnata on mesenchymal stem cells derived from gingiva.

\section{Methods}

\section{Preparation of the materials}

Pongamia pinnata (L.) Pierre was collected from Noakhali in Bangladesh by Md Salah Uddin. A voucher specimen recoded as PB022015 was deposited in the herbarium of the Korea Research Institute of Bioscience and Biotechnology. The dried seeds of Pongamia pinnata were ground. Five hundred $\mathrm{mL}$ of methanol was added to $58 \mathrm{~g}$ of the powder. The repercolation method was used for the extraction process at room temperature. The resultant product was filtered and concentrated under reduced pressure. Finally, $15.04 \mathrm{~g}$ of methanol extract of Pongamia pinnata (PPT) was obtained.

\section{Isolation of stem cells from human tissue}

The gingivae were obtained from healthy patients visiting the Department of Periodontics, Seoul St. Mary's Hospital, College of Medicine, the Catholic University of Korea. The Institutional Review Board reviewed and approved the study (KC11SISI0348). The participants signed informed consent forms. All the procedures were performed in accordance with the relevant guidelines and regulations. Isolation procedures were done based on the previous publication. ${ }^{16)}$ In short, the obtained gingiva was digested with dispase (Sigma-Aldrich Co., St. Louis, $\mathrm{MO}$, USA) at $1 \mathrm{mg} / \mathrm{mL}$ and collagenase IV (Sigma-Aldrich Co) at a $2 \mathrm{mg} / \mathrm{mL}$ concentration.

\section{Evaluation of cellular morphology}

Stem cells were plated at a density of $2.0 \times 10^{3}$ cells/well in an osteogenic medium (alpha-minimal essential medium (a-MEM, Gibco, Grand Island, NY, USA) supplemented with $15 \%$ fetal bovine serum (FBS, Gibco), $200 \mathrm{mM}$ L-glutamine (Sigma-Aldrich Co.), $10 \mathrm{mM}$ of ascorbic acid 2-phosphate (Sigma-Aldrich Co.), $38 \mathrm{ug} / \mathrm{ml}$ of dexamethasone, $2 \mathrm{mg} / \mathrm{ml}$ of glycerophosphate disodium salt hydrate, and $100 \mathrm{U} / \mathrm{mL}$ penicillin, and $100 \mathrm{\mu g} / \mathrm{mL}$ streptomycin (Sigma-Aldrich Co.)) The final concentrations of PPT were $0 \%, 0.001 \%$, $0.01 \%, 0.1 \%$, and $1 \%$, respectively. The morphological evaluation was performed on Day 1 using inverted microscopy (CKX41SF, Olympus Corporation, Tokyo, Japan).

\section{Evaluation of cellular viability}

The cellular viability was evaluated on Day 1 based on the previous report using the Counting Kit-8 (CCK-8, Dojindo, Tokyo, Japan) assay. ${ }^{17)}$ In short, cells were incubated with tetrazolium monosodium salt for 2 hours at $37{ }^{\circ} \mathrm{C}$. Spectrophotometric absorbance at $450 \mathrm{~nm}$ was 
measured using a microplate reader (BioTek Instruments Inc., Winooski, VT, USA).

\section{Alkaline phosphatase activity assays}

Alkaline phosphatase activity assays were done on Days 3 and 7 using a commercially available kit (K412-500, BioVision, Inc., Milpitas, CA, USA). A microplate reader (BioTek Instruments Inc.) was used to measure the spectrophotometric absorbance of the samples.

\section{Evaluation of Alizarin Red S staining}

On Days 3 and 7, Alizarin Red S staining was performed. In short, the cells were washed, fixed, and stained with 2\% Alizarin Red S Solution (ScienCell Research Laboratories, Inc., Carlsbad, CA, USA) and evaluated with a microscope (CKX41SF, Olympus Corporation). Ten percent cetylpyridinium chloride (Sigma-Aldrich Co.) was used to solubilize the bound dye, and spectrophotometric quantification was performed at $560 \mathrm{~nm}$ (BioTek Instruments Inc.).

\section{Statistical analysis}

The data are presented as means \pm standard deviations. A test of normality was performed and a one-way analysis of variance with a post hoc test was performed to determine the differences between the groups. The tests were performed using a commercially available program (SPSS 12 for Windows, SPSS Inc., Chicago, IL, USA), and the level of significance was 0.05 .

\section{Results}

\section{Evaluation of cell morphology}

The morphology of stem cells treated with PPT at final concentrations of $0 \%, 0.001 \%, 0.01 \%, 0.1 \%$, and $1 \%$ on Day 1 is shown in Figure 1. Stem cells in the control group showed fibroblast-like morphology on Day 1 (Figure 1A). The morphology of stem cells in the presence of PPT at final concentrations of $0 \%, 0.001 \%, 0.01 \%, 0.1 \%$, and $1 \%$ did not produce any noticeable changes when compared with the untreated control group (Figures 1B-1E).

\section{Cellular viability}

Results from the CCK8 assay revealed cellular viability on Day 1 and are shown in Figure 2. The relative values of CCK- 8 at Day 1 for $0.001 \%$, $0.01 \%, 0.1 \%$, and $1 \%$ are $94.0 \pm 5.4,94.3 \pm 7.2$, $91.1 \pm 4.9$, and $86.5 \pm 5.2$, respectively, when the control $(0 \%)$ group at Day 1 is considered $100 \%$ $(100.0 \pm 5.1 \%)(P>0.05)$.

\section{Alkaline phosphatase activity assays}

The alkaline phosphatase activity treated with PPT at Days 3 and 7 is shown in Figure 3. The absorbance values of cells on Day 3 grown with $0 \%$, $0.001 \%, 0.01 \%, 0.1 \%$, and $1 \%$ PPT were $0.073 \pm$ $0.000,0.075 \pm 0.001,0.083 \pm 0.000,0.078 \pm 0.002$, 0.001 , and $0.081 \pm 0.001$, respectively. The treatment of PPT (from 0.001 to $1 \%$ groups) showed a statistically significant increase in alkaline phosphatase activity when compared to the control group at Day $3(P<0.05)$. Application of PPT produced a statistically significant increase of alkaline phosphatase activity with the highest value at $0.01 \%$. The absorbance values of cells on Day 7 grown with $0 \%, 0.001 \%, 0.01 \%, 0.1 \%$, and $1 \%$ PPT were $0.104 \pm 0.001,0.110 \pm 0.000,0.122 \pm 0.001$, $0.130 \pm 0.001$, and $0.121 \pm 0.000$, respectively $(P<$ $0.05)$. Similarly, application of PPT produced a statistically significant increase of alkaline phosphatase activity and the highest value was seen at $0.1 \%$ group.

\section{Mineralization assay}

The results of the Alizarin Red S staining on Days 3 and 7 following treatment with different 

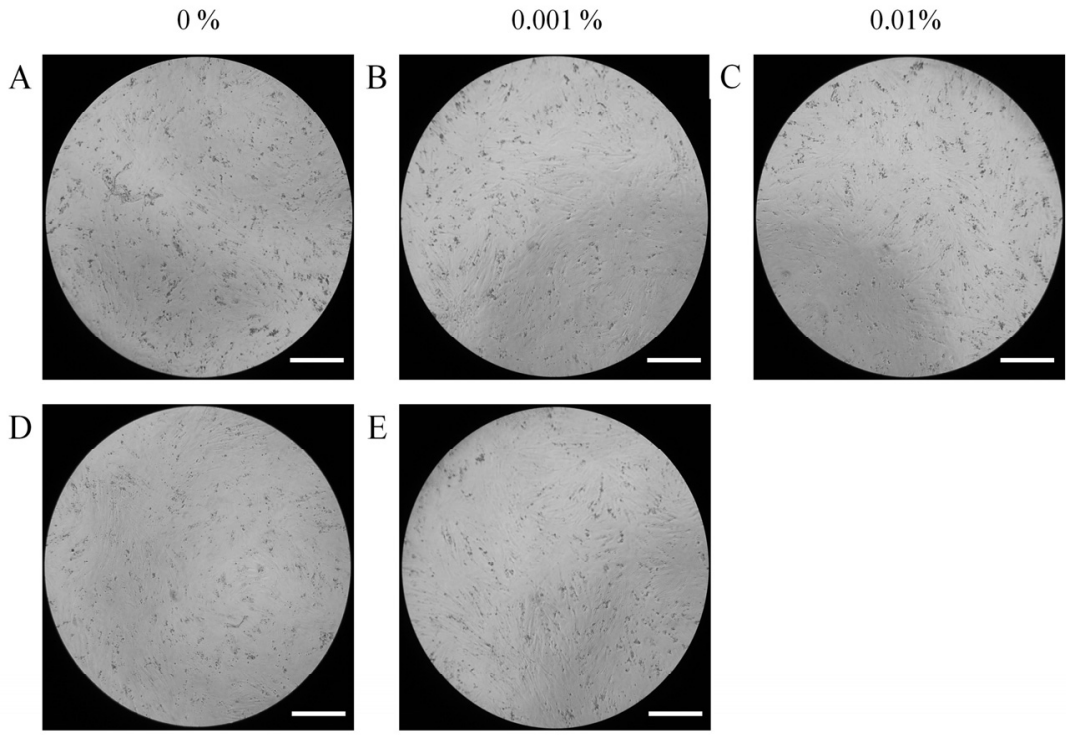

$0.1 \%$

$1 \%$

Fig. 1. Evaluation of cell morphology on Day 1 using inverted microscopy following treatment with different concentrations of PPT in osteogenic media.

A. Control group (original magnification $\times 200$ )

B. $0.001 \%$ group (original magnification $\times 200$ )

C. $0.01 \%$ group (original magnification $\times 200$ )

D. $0.1 \%$ group (original magnification $\times 200$ )

E. $1 \%$ group (original magnification $\times 200$ )

The bar indicates $200 \mu \mathrm{m}$.

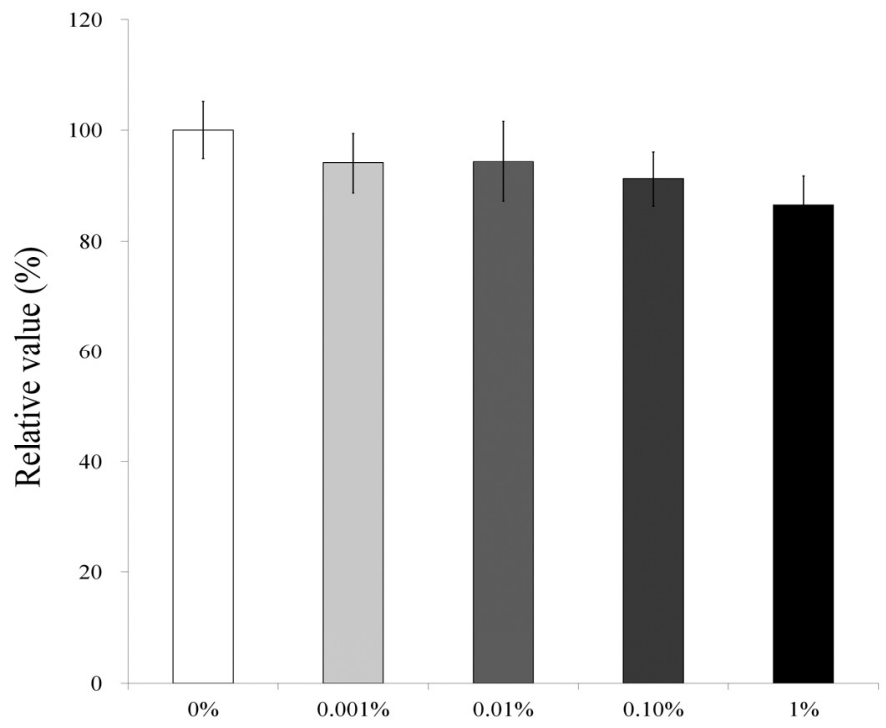

Fig. 2. The CCK-8 assay results at Day 1 cultured with osteogenic media. The data are presented as means \pm standard deviations. 


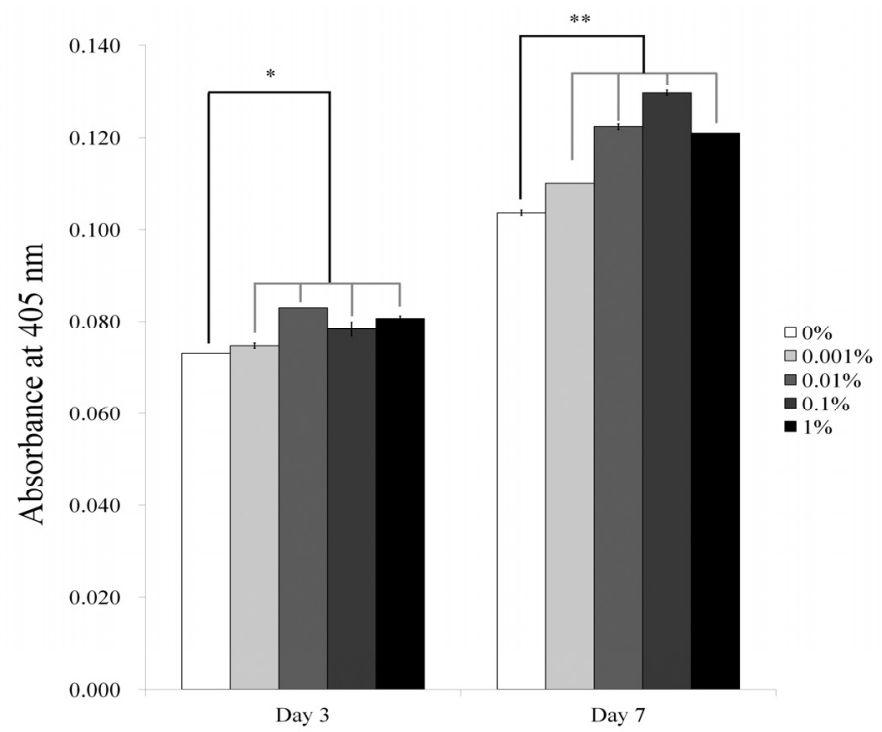

Fig. 3. Alkaline phosphatase activity on Days 3 and 7.

The data are presented as means \pm standard deviations.

* Statistically significant differences were noted when compared with the data from the control group at Day $3(P<0.05)$.

** Statistically significant differences were noted when compared with the data from the control group at Day $7(P<0.05)$.

$0 \%$

A

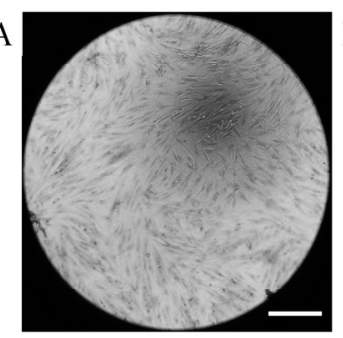

$\mathrm{D}$

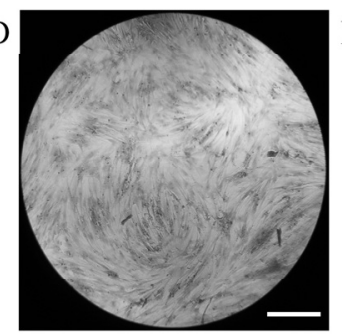

$0.1 \%$
$0.001 \%$
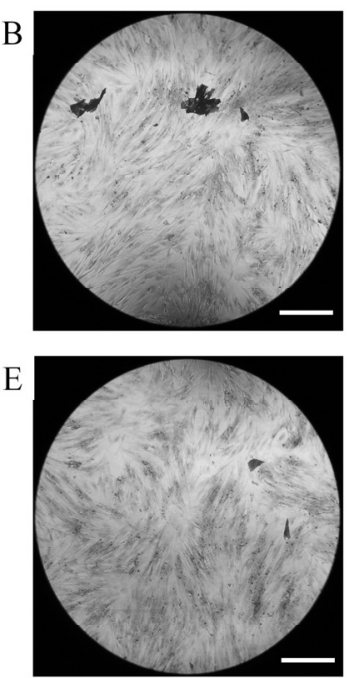

$1 \%$
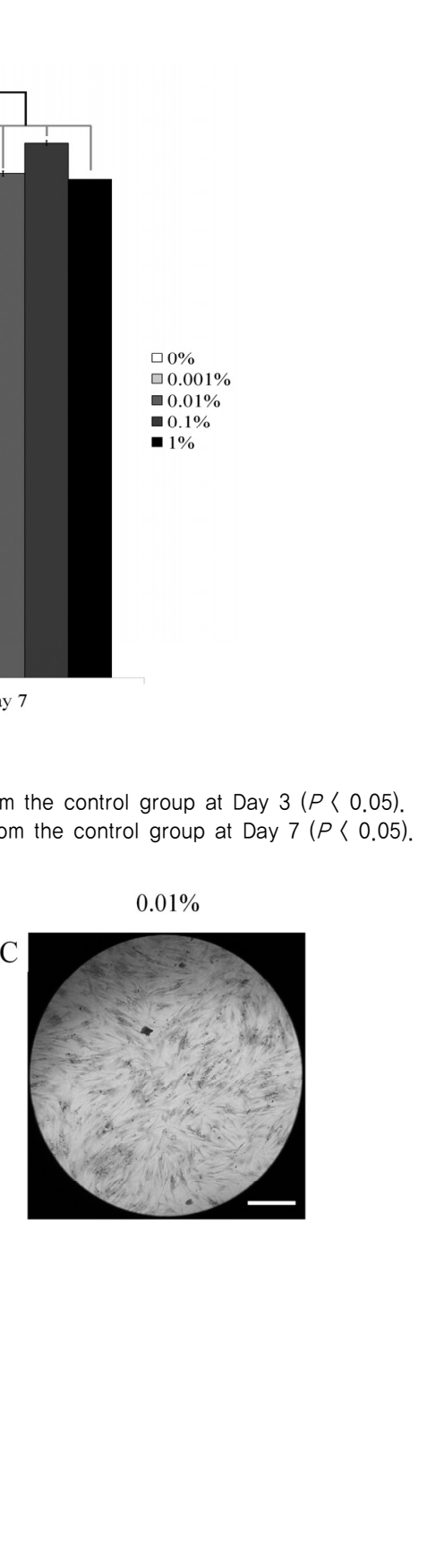

Fig. 4. Results of Alizarin Red S staining on Day 3 following treatment with different concentrations of PPT on osteogenic supplement.

A. Control group (original magnification $\times 100$ )

B. $0.001 \%$ group (original magnification $\times 100$ )

C. $0.01 \%$ group (original magnification $\times 100$ )

D. $0.1 \%$ group (original magnification $\times 100$ )

E. $1 \%$ group (original magnification $\times 100$ )

The bar indicates $400 \mu \mathrm{m}$. 
$0 \%$
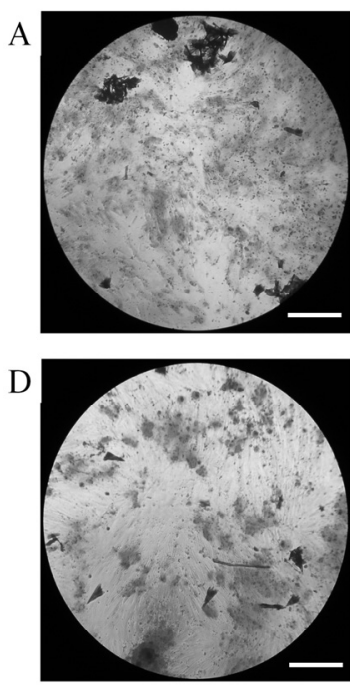

$0.1 \%$
$0.001 \%$
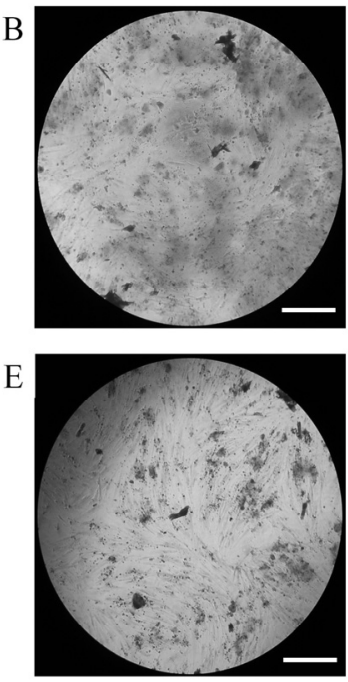

$1 \%$
$0.01 \%$
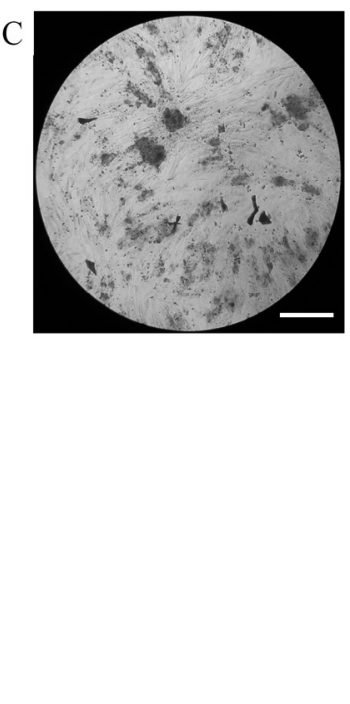

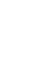

Fig. 5. Results of Alizarin Red S staining on Day 7 following treatment with different concentrations of PPT on osteogenic supplement.

A. Control group (original magnification $\times 100$ )

B. $0.001 \%$ group (original magnification $\times 100$ )

C. $0.01 \%$ group (original magnification $\times 100$ )

D. $0.1 \%$ group (original magnification $\times 100$ )

E. $1 \%$ group (original magnification $\times 100$ )

The bar indicates $400 \mu \mathrm{m}$.

concentrations of PPT in an osteogenic supplement are shown in Figures 4-5. The absorbance of cells on Day 3 cultured with $0 \%, 0.001 \%, 0.01 \%, 0.1 \%$, and $1 \%$ PPT was $0.059 \pm 0.002,0.044 \pm 0.002,0.052 \pm$ $0.005,0.049 \pm 0.004$, and $0.063 \pm 0.002$, respectively (Figure 6). The absorbance of cells on Day 7 cultured with $0 \%, 0.001 \%, 0.01 \%, 0.1 \%$, and $1 \%$ PPT was $0.082 \pm 0.002,0.102 \pm 0.001,0.085 \pm 0.002$, $0.084 \pm 0.007$, and $0.080 \pm 0.001$, respectively. A statistically significant increase of absorbance was noted with the $0.001 \%$ group on Day $7(P<0.05)$.

\section{Discussion}

This report discusses the effects of different concentrations of PPT on the osteogenic differentiation of stem cells derived from gingival tissues. This study clearly showed that short-term application of PPT enhanced the proliferation of mesenchymal stem cells.

The application of a low dose of PPT enhanced alkaline phosphatase activity up to $25 \%$ and mineralization up to $24 \%$. Alkaline phosphatase activity is used for the evaluation of early osteogenic differentiation. ${ }^{1)}$ and Alizarin red S staining assay measures the presence of calcium in cellular deposits which is used for the evaluation of early matrix mineralization. ${ }^{17}$ Alkaline phosphatase activities increased between 3 and 7 days and mineralization increased between 3 and 7 Days. The highest alkaline phosphatase activity was achieved with $0.01 \%$ PPT on Day 3 and $0.01 \%$ group on Day 7 . A significant increase in mineralization was 


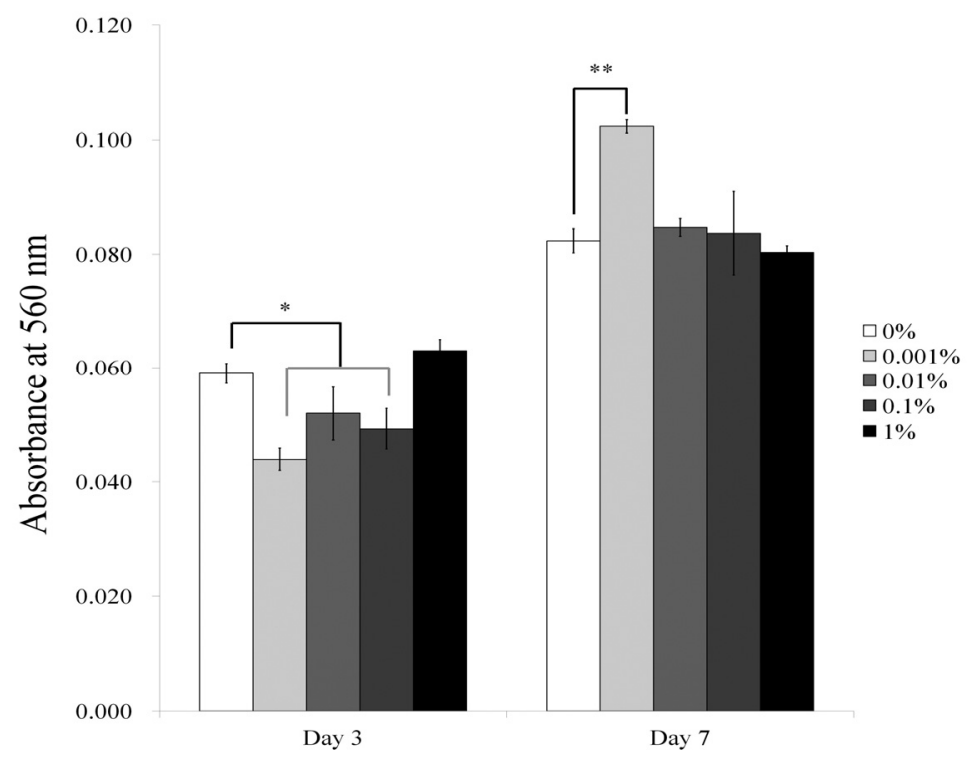

Fig. 6. Quantitative results of Alizarin Red S staining on Days 3 and 7.

The data are presented as means \pm standard deviations.

* Statistically significant differences were noted when compared with the data from the control group at Day $3(P<0.05)$.

** Statistically significant differences were noted when compared with the data from the control group at Day $7(P<0.05)$.

achieved in the $0.001 \%$ PPT group on Day 7. Different dosages may produce different effects on stem cells. A previous report showed that lower concentrations of a traditional herb enhanced the total metabolic activity and their alkaline phosphatase activity expression, but high concentrations significantly depressed the cell population. ${ }^{18)}$ It should be considered that there could be variations in doses to achieve the maximal effect, depending on the stage of cultured cell, the system, and the culture period. ${ }^{19)}$

In this study, methanol extracts of Pongamia pinnata were used. Various methods can be used for the extraction of herbs, including cold pressing, expeller pressing, and solvent extraction.-5,11) Different kinds of solvents including ethanol, methanol, butanol, hexane, methylene chloride, ethyl acetate, and water can be used for the extraction. A relatively higher temperature is applied in expeller pressing when compared with cold pressing. ${ }^{20)}$ Previous report showed that methanol extract showed higher functionality without compromising cellular viability and this study used methanol extract of Pongamia pinnata for the evaluation. ${ }^{21)}$ Different alcohol extracts including methanol, ethanol, and butanol may have different effects with different boiling points and solubility. ${ }^{22,}$,23)

Human stem cells have been isolated and characterized from various tissues including bone marrow, periosteum, adipose tissue, and muscle. ${ }^{16)}$ Previous reports showed that mesenchymal stem cells derived from gingival tissue could be a novel source for stem cell-based therapy in bone reconstruction in clinical applications. ${ }^{24}$ It was shown that mesenchymal stem cells derived from human gingival tissue were superior to bone marrow-derived mesenchymal stem cells for cell therapy in 
regenerative medicine. ${ }^{25)}$ Similar to another source of stem cells, immunomodulatory properties were found with dental tissue-derived mesenchymal stem cells. ${ }^{26}$ It should be emphasized that stem cells derived from gingival tissue have several advantages, including ease of isolation, accessible tissue source, and rapid ex vivo expansion. ${ }^{27)}$

Herbal extracts have been delivered with the use of scaffold materials including calcium silicate and tricalcium phosphate. ${ }^{28,29)}$ Calcium silicate has been applied with herbal extracts after seeding with human adipose-derived stem cells, and it was shown that the use of herbal extracts produced higher alkaline phosphatase activity, greater osteocalcin protein secretion, and clearly calcified tissue mineralization. ${ }^{28)}$ Extracts from Epimedium were incorporated into poly lactic-co-glycolic acid/tricalcium phosphate using fine-spinning technology, and the supplement of scaffold materials with herbal medicine demonstrated enhanced bone repair with sustainable release. ${ }^{29}$

Based on these findings, it was concluded that PPT could produce beneficial effects on mesenchymal stem cells with enhanced osteogenic differentiation.

\section{Acknowledgements}

This study was partly supported by Research Fund of Seoul St. Mary's Hospital, The Catholic University of Korea and Catholic Institute of Cell Therapy (CIC, Seoul, Korea). This study was also partly funded by the Ministry of Science, ICT and Future Planning, Republic of Korea government (NRF-2016K1A1A8A01939075), and partly supported by Basic Science Research Program through the National Research Foundation of Korea (NRF) funded by the Ministry of Science, Information and Communication Technology \& Future Planning (NRF-2017R1 A1A1A05001307).

\section{Competing interests}

The authors report no conflicts of interest related to this study. The author does not have any financial interest in the companies whose materials are included in the article.

\section{Ethics statement}

All procedures performed in studies involving human participants were in accordance with the ethical standards of the institutional and/or national research committee and with the 1964 Helsinki Declaration and its later amendments or comparable ethical standards.

\section{Informed consent}

Informed consents were received from the participants.

\section{References}

1. Ha DH, Pathak S, Yong CS, Kim JO, Jeong JH, Park JB. Potential differentiation ability of gingiva originated human mesenchymal stem cell in the presence of tacrolimus. Sci Rep. 2016;6:34910.

2. Maumus M, Jorgensen C, Noel D. Mesenchymal stem cells in regenerative medicine applied to rheumatic diseases: role of secretome and exosomes. Biochimie. 2013;95:2229-2234.

3. Jeong SH, Lee JE, Jin SH, Ko Y, Park JB. Effects of Asiasari radix on the morphology and viability of mesenchymal stem cells derived from the gingiva. Mol Med Rep. 2014;10:3315 -3319 .

4. Jeong SH, Kim BB, Lee JE, Ko Y, Park JB. Evaluation of the effects of Angelicae dahuricae radix on the morphology and viability of mesenchymal stem cells. Mol Med Rep. 
2015;12:1556-1560.

5. Jeong SH, Lee JE, Kim BB, Ko Y, Park JB. Evaluation of the effects of Cimicifugae Rhizoma on the morphology and viability of mesenchymal stem cells. Exp Ther Med. 2015;10:629-634.

6. Zhang N, Kang T, Xia Y, Wen Q, Zhang X, Li $\mathrm{H}$, et al. Effects of salvianolic acid $\mathrm{B}$ on survival, self-renewal and neuronal differentiation of bone marrow derived neural stem cells. Eur J Pharmacol. 2012;697:32-39.

7. Yang L, Wang NL, Cai GP. Maohuoside A promotes osteogenesis of rat mesenchymal stem cells via BMP and MAPK signaling pathways. Mol Cell Biochem. 2011;358:37-44.

8. Qian K, Xu H, Dai T, Shi K. Effects of Tanshinone IIA on osteogenic differentiation of mouse bone marrow mesenchymal stem cells. Naunyn Schmiedebergs Arch Pharmacol. 2015; 388:1201-1209.

9. Cai M, Li G, Tao K, Yang Y, Lou L, Cai Z, et al. Maohuoside A acts in a BMP-dependent manner during osteogenesis. Phytother Res. 2013;27:1179-1184.

10. Kim DR, Lee JE, Shim KJ, Cho JH, Lee HC, Park SK, et al. Effects of herbal Epimedium on the improvement of bone metabolic disorder through the induction of osteogenic differentiation from bone marrow-derived mesenchymal stem cells. Mol Med Rep. 2017;15: 125-130.

11. Kim SY, An SY, Lee JS, Heo JS. Zanthoxylum schinifolium enhances the osteogenic potential of periodontal ligament stem cells. In Vitro Cell Dev Biol Anim. 2015;51:165-173.

12. Li J, Jiang Z, Li X, Hou Y, Liu F, Li N, et al. Natural therapeutic agents for neurodegenerative diseases from a traditional herbal medicine Pongamia pinnata (L.) Pierre. Bioorg Med Chem Lett. 2015;25:53-58.

13. Al Muqarrabun LM, Ahmat N, Ruzaina SA, Ismail NH, Sahidin I. Medicinal uses, phytochemistry and pharmacology of Pongamia pinnata (L.) Pierre: a review. J Ethnopharmacol. 2013;150:395-420.

14. Brijesh S, Daswani PG, Tetali P, Rojatkar SR, Antia NH, Birdi TJ. Studies on Pongamia pinnata (L.) Pierre leaves: understanding the mechanism(s) of action in infectious diarrhea. $J$ Zhejiang Univ Sci B. 2006;7:665-674.

15. Carcache-Blanco EJ, Kang YH, Park EJ, Su BN, Kardono LB, Riswan S, et al. Constituents of the stem bark of Pongamia pinnata with the potential to induce quinone reductase. $\mathrm{J}$ Nat Prod. 2003;66:1197-1202.

16. Jin SH, Lee JE, Yun JH, Kim I, Ko Y, Park JB. Isolation and characterization of human mesenchymal stem cells from gingival connective tissue. J Periodontal Res. 2015;50: 461-467.

17. Ha DH, Yong CS, Kim JO, Jeong JH, Park JB. Effects of tacrolimus on morphology, proliferation and differentiation of mesenchymal stem cells derived from gingiva tissue. Mol Med Rep. 2016;14:69-76.

18. Liu YR, Qu SX, Maitz MF, Tan R, Weng J. The effect of the major components of Salvia Miltiorrhiza Bunge on bone marrow cells. J Ethnopharmacol. 2007;111:573-583.

19. Park JB, Zhang H, Lin CY, Chung CP, Byun Y, Park YS, et al. Simvastatin maintains osteoblastic viability while promoting differentiation by partially regulating the expressions of estrogen receptors alpha. J Surg Res. 2012;174:278-283.

20. Yazdani-Nasab Z, Piravi-Vanak Z. A Study on the Specifications of Cold Pressed Colza Oil. Recent Pat Food Nutr Agric. 2015;7:47-52.

21. Jeong SH, Jiang Y, Guo H, Wang MH, Park JB. Anti-inflammatory and anticancer effects of methanol, ethanol and water extracts of Asiasarum heterotropoide. Biomed Rex. 2016;27:103-109.

22. Mukudai Y, Zhang M, Shiogama S, Kondo S, Ito $\mathrm{C}$, Motohashi $\mathrm{H}$, et al. Methanol and Butanol 
Extracts of Paeonia lutea Leaves Repress Metastasis of Squamous Cell Carcinoma. Evid Based Complement Alternat Med. 2016;2016: 6087213.

23. Wang MH, Jeong SH, Guo H, Park JB. Anti-inflammatory and cytotoxic effects of methanol, ethanol, and water extracts of Angelicae Dahuricae Radix. J Oral Sci. 2016; 58:125-131.

24. Wang F, Yu M, Yan X, Wen Y, Zeng Q, Yue $\mathrm{W}$, et al. Gingiva-derived mesenchymal stem cell-mediated therapeutic approach for bone tissue regeneration. Stem Cells Dev. 2011;20: 2093-2102.

25. Tomar GB, Srivastava RK, Gupta N, Barhanpurkar AP, Pote ST, Jhaveri HM, et al. Human gingiva-derived mesenchymal stem cells are superior to bone marrow-derived mesenchymal stem cells for cell therapy in regenerative medicine. Biochem Biophys Res Commun.
2010;393:377-383.

26. Li Z, Jiang CM, An S, Cheng Q, Huang YF, Wang YT, et al. Immunomodulatory properties of dental tissue-derived mesenchymal stem cells. Oral Dis. 2014;20:25-34.

27. Zhang QZ, Nguyen AL, Yu WH, Le AD. Human oral mucosa and gingiva: a unique reservoir for mesenchymal stem cells. $J$ Dent Res. 2012;91:1011-1018.

28. Chang NJ, Chen YW, Shieh DE, Fang HY, Shie MY. The effects of injectable calcium silicate-based composites with the Chinese herb on an osteogenic accelerator in vitro. Biomed Mat. 2015;10:055004.

29. Wang XL, Xie XH, Zhang G, Chen SH, Yao D, $\mathrm{He} \mathrm{K}$, et al. Exogenous phytoestrogenic molecule icaritin incorporated into a porous scaffold for enhancing bone defect repair. J Orthop Res. 2013;31:164-172. 